\title{
Interaction between Colletotrichum lindemuthianum Races and Gene Pool Diversity in Phaseolus vulgaris
}

\author{
R.S. Balardin ${ }^{1}$ and J.D. Kelly \\ Crop and Soil Sciences Department, Michigan State University, East Lansing, MI 48824
}

Amotronal Index words. multivariate analysis, Andean gene pool, Middle American gene pool, Phenetic analysis, variability, coevolution

\begin{abstract}
Abstracr. Sixty-two genetically diverse modern and traditional Phaseolus vulgaris L. cultivars from Brazil, the Dominican Republic, Honduras, Mexico, the Netherlands, and the United States, representative of the Andean and Middle American gene pools, were selected to study the interaction with distinct races of Colletotrichum lindemuthianum (Sacc. \& Magnus) Lams.Scrib. Principal component and phenetic analyses were conducted on the disease reaction to inoculation with 34 races of $C$. lindemuthianum from Argentina, Brazil, Colombia, Costa Rica, the Dominican Republic, Honduras, Mexico, Peru, and the United States. The principal component analysis revealed four clusters in which only one cluster consisted of cultivars from both gene pools. Bean genotypes clustered based on the gene pool origin of the resistance genes present, regardless of the actual gene pool of the host genotype. Middle American genotypes in cluster A carried Andean resistance genes. Further grouping of genotypes based on overall level of resistance within each gene pool was observed. Clusters $A$ and $C$ consisted of the most resistant genotypes from both gene pools. The distribution of genotypes generated by the phenetic analysis, placed the most resistant and susceptible genotypes of the anthracnose differential series at the extremities of the phenogram, providing support for the range in genotypic resistance exhibited by members of the differential series. Races of $C$. lindemuthianum isolated from Middle American genotýpes showed broad virulence on germplasm from both gene pools, whereas races with Andean reaction showed high virulence only on Andean germplasm. The reduced virulence of Andean races on Middle American genotypes suggests selection of virulence factors congruent with diversity in $P$. vulgaris. In addition, races of $C$. lindemuthianum formed two clusters corresponding to the Middle American and Andean reaction groups based on the phenetic analysis. In the principal component analysis, most races with the Andean reaction were observed in the clusters $\mathrm{C}$ and D, except races 15 and 23 which clustered with Middle American races in cluster B. Only races 38, 39 and 47 from the Dominican Republic showed high similarity in both multivariate analyses and clustered based on geographic origin. Races from other countries showed no geographic effect. The overlapping of specific races, however, with races from different reaction groups might indicate that this group of isolates possesses factors of virulence to both host gene pools. Data based on virulence supports variability in $C$. lindemuthianum structured with diversity in $P$. vulgaris.
\end{abstract}

Anthracnose, caused by Colletotrichum lindemuthianum, is an endemic, worldwide disease of common bean (Phaseolus vulgaris L.). Disease severity is greater in highland Central American countries than in South American or temperate regions of North America and Europe (Pastor-Corrales et al., 1994). Yield losses from anthracnose can be as high as $95 \%$ (Guzman et al., 1979). Control of this disease is difficult due to the efficient seed transmission of the pathogen (Tu, 1992), seasonal survival in plant debris (Dillard and Cobb, 1993), eventual development of sclerotia (Sutton, 1992) and lack of cost-effective chemical control (PastorCorrales and $\mathrm{Tu}, 1989$ ). Although the most effective approach to control this disease is through an integrated pest management (IPM) regime, host resistance seems to be more appropriate in countries where implementation of IPM measures is not feasible. The major limitation for developing durable resistance in commercial germplasm, however, is the magnitude of variability in $C$. lindemuthianum reported worldwide (Andrus and Wade, 1942; Balardin et al., 1990; Barrus, 1918; Blondet, 1963; Burkholder, 1923; Fouilloux, 1979; Garrido, 1986; Menezes and Dianese, 1988; Waterhouse, 1955).

Evolving races of $C$. lindemuthianum continue to overcome

Received for publication 6 Nov. 1997. Accepted for publication 10 July 1998. This research was supported in part by the grant DAN 1310-G-SS-6008-00 from the USAID Bean/Cowpea Collaborative Research Support Program and the Michigan Agricultural Experiment Station. Support for senior author (RSB) from Brazilian Education and Culture Ministry, CAPES, and Federal University of Santa Maria (UFSM) Brazil, is recognized. The cost of publishing this paper was defrayed in part by the payment of page charges. Under postal regulations, this paper therefore must be hereby marked advertisement solely to indicate this fact.

${ }^{1}$ Current address: Universidade Federal de Santa Maria, Depto. Defesa Fitosanitaria, 97119-000 Santa Maria, Rio Grande de Sul, Brazil. specific resistance genes in $P$. vulgaris (Kelly et al., 1994). Before the appearance of race 23 (delta) of $C$. lindemuthianum, the $\mathrm{Co}-1$ gene was the only resistance source used in commercial navy beans in North America (Tu, 1988). The $\mathrm{Co}$ - 2 gene, which confers resistance to races $17,130,102,23,65$, and 55, was the predominant resistance source used in Europe (Mastenbroek, 1960; Kruger et al., 1977; Fouilloux, 1979). The appearance of races kappa (31) iota, and alphaBrazil (89) in Europe and Brazil (Kruger et al., 1977; Fouilloux, 1979) capable of defeating the $\mathrm{Co}-2$ gene, however, necessitated the search for new resistance sources. Three new resistance genes, $\mathrm{Co}$ $3, \mathrm{Co}-4$, and $\mathrm{Co}-5$ were characterized in a collection of bean germplasm from Mexico (Fouilloux, 1979). The $\mathrm{Co}-4$ and $\mathrm{Co}-5$ genes confer resistance to all three races (kappa, iota and alpha-Brazil), whereas race alpha-Brazil overcomes the $\mathrm{Co}-3$ gene.

Long-term resistance based on major genes has not always been effective when resistance genes are deployed one at a time (Duvick, 1996). For instance, bean genotypes TO (Co-4), PI 207262, and Mexico $222(\mathrm{Co}-3)$, reported to be resistant to European and North American races (Kruger et al., 1977; Fouilloux, 1979; Schwartz et al., 1982), were susceptible to Latin American races (Menezes and Dianese, 1988; Pastor-Corrales et al., 1995; Rava et al., 1993; Restrepo, 1994; Rodriguez, 1991). Isolates from Honduras overcame resistance in TU $(\mathrm{Co}-5)$ and $\mathrm{AB} 136(\mathrm{Co}-6)$ (Balardin et al., 1997), cultivars widely used as parents in various breeding programs in Latin America. Combining complementary resistance genes has been proposed as an approach to developing durable resistance in other crops (Duvick, 1996; Casela et al., 1995; Levy et al., 1993). In common bean, pyramiding resistance genes from the two major Phaseolus gene pools (Middle American and Andean) was suggested as an approach to develop long-term resistance to anthracnose (Young and Kelly, 1997). 


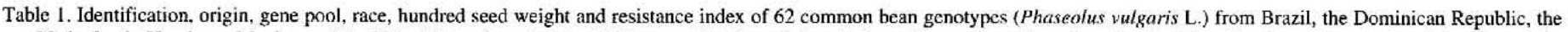
Netherlands, Honduras, Mexico, and the United States inoculated with 34 races of Colletotrichum lindemuthianum from Argentina, Brazil, Colombia, Costa Rica, the Dominican Republic, Honduras, Mexico, Peru, and the United States.

\begin{tabular}{|c|c|c|c|c|c|c|}
\hline No. & Genotype $^{2}$ & Origin ${ }^{y}$ & GP $^{*}$ & Race $^{*}$ & $\mathrm{sw}^{*}$ & $\mathrm{RI}^{\prime \prime}$ \\
\hline 1 & MDRK & US & A & Nueva Granada & 54.9 & 56 \\
\hline 2 & Perry Marrow & US & A & Nueva Granada & 44.2 & 59 \\
\hline 3 & Charlevoix & US & A & Nueva Granada & 53.0 & 41 \\
\hline 4 & Seafarer & US & M & Meso America & 17.2 & 47 \\
\hline 5 & Montcalm & US & A & Nueva Granada & 54.0 & 35 \\
\hline 6 & Red Hawk & US & A & Nueva Grunada & 56.0 & 44 \\
\hline 7 & Widusa & Nth & M & Meso America & 30.0 & 70 \\
\hline 8 & Pinto Villa & Mex & M & Durango & 37.2 & 67 \\
\hline 9 & Bayo Victoria & Mex & M & Durango & 44.0 & 67 \\
\hline 10 & Isles & US & A & Nueva Granada & 62.0 & 74 \\
\hline 11 & Kaboon & Nth & A & Nueva Granada & 36.1 & 79 \\
\hline 12 & PC-50 & DR & A & Nueva Granada & 44.7 & 64 \\
\hline 13 & Ruddy & US & A & Nueva Granada & 52.0 & 44 \\
\hline 14 & Cacahuate 72 & Mex & A & Nueva Granada & 43.5 & 18 \\
\hline 15 & Chihuahua 21 & Mex & A & Nueva Granada & 35.5 & 6 \\
\hline 16 & Bayomex & Mex & A & Nucva Granada & 42.5 & 6 \\
\hline 17 & Isabella & US & A & Nueva Granada & 51.0 & 0 \\
\hline 18 & Cardinal & US & A & Nueva Granada & 62.0 & 3 \\
\hline 19 & Taylor Horticultural & US & A & Nueva Granada & 54.0 & 3 \\
\hline 20 & G 2333 & Mex & $\mathbf{M}$ & Jalisco & 18.8 & 100 \\
\hline 21 & SEL. 1308 & US & M & Meso America & 24.0 & 97 \\
\hline 22 & Catrachita & Hon & $\mathbf{M}$ & Meso America & 31.2 & 94 \\
\hline 23 & BAT 93 & US & M & Meso America & 17.0 & 85 \\
\hline 24 & SEL 1360 & US & $\mathrm{M}$ & Meso America & 24.0 & 97 \\
\hline 25 & TO & Mex & M & Meso America & 28.4 & 73 \\
\hline 26 & AB 136 & Mex & $\mathbf{M}$ & Meso America & 23.8 & 91 \\
\hline 27 & PI 207262 & Mex & M & Meso America & 20.2 & 79 \\
\hline 28 & FM M38 & Mex & M & Jalisco & 28.2 & 82 \\
\hline 29 & Yeguare & Hon & M & Meso America & 19.0 & 79 \\
\hline 30 & Macanudo & Bra & M & Meso America & 23.3 & 65 \\
\hline 31 & Negro 150 & Mex & $\mathrm{M}$ & Jalisco & 29.0 & 62 \\
\hline 32 & Zacatecas 15 & Mex & M & Durango & 14.5 & 67 \\
\hline 33 & $\mathrm{TU}$ & Mex & $\mathrm{M}$ & Meso America & 21.2 & 88 \\
\hline 34 & Blackhawk & US & M & Meso America & 19.0 & 67 \\
\hline 35 & Newport & US & $\mathbf{M}$ & Meso America & 25.0 & 59 \\
\hline 36 & Cornell 49242 & US & $\mathbf{M}$ & Meso America & 17.7 & 65 \\
\hline 37 & Mexico 222 & Mex & $\mathbf{M}$ & Meso America & 25.1 & 59 \\
\hline 38 & Amarillo de Calpan & Mex & $\mathbf{M}$ & Jalisco & 27.5 & 50 \\
\hline 39 & Rio Tibagi & Bra & $\mathbf{M}$ & Meso America & 21.0 & 51 \\
\hline 40 & Amarillo 169 & Mex & $\mathbf{M}$ & Jalisco & 21.7 & 47 \\
\hline 4J & Flor de Mayo & Mex & $\mathrm{M}$ & Jalisco & 22.8 & 23 \\
\hline 42 & Puebla 36 & Mex & $\mathrm{M}$ & Jalisco & 24.0 & 35 \\
\hline 43 & $C-20$ & US & M & Meso America & 18.4 & 41 \\
\hline 44 & Michoacan 8-A & Mex & $M$ & Jalisco & 27.5 & 35 \\
\hline 45 & Durango 32 & Mex & $\mathbf{M}$ & Durango & 20.0 & 26 \\
\hline 46 & Gilguerillo & Mex & $\mathbf{M}$ & Jalisco & 24.5 & 38 \\
\hline 47 & Carioca & Bra & $\mathbf{M}$ & Meso America & 18.5 & 38 \\
\hline 48 & Criollo Negro & Mex & $\mathrm{M}$ & Meso America & 26.8 & 35 \\
\hline 49 & MD 2324 & Hon & $\mathbf{M}$ & Meso America & 20.5 & 38 \\
\hline 50 & Tio Canela 75 & Hon & $\mathbf{M}$ & Meso America & 17.5 & 15 \\
\hline 51 & Schooner & US & M & Meso America & 19.0 & 23 \\
\hline 52 & Bayo Berrendo & Mex & $\mathrm{M}$ & Meso America & 17.5 & 17 \\
\hline 53 & MD 3037 & Hon & M & Meso America & 22.8 & 24 \\
\hline 54 & Azufrado & Mex & M & Durango & 28.0 & 41 \\
\hline 55 & T-39 & US & M & Meso America & 20.0 & 23 \\
\hline 56 & Negro Durango & Mex & M & Durango & 32.5 & 17 \\
\hline 57 & Dorado & Hon & $\mathbf{M}$ & Meso America & 23.0 & 26 \\
\hline 58 & Desarrural IR & Hon & $\mathbf{M}$ & Meso America & 17.0 & 3 \\
\hline 59 & Danli 46 & Hon & $\mathbf{M}$ & Meso America & 22.8 & 17 \\
\hline 60 & Zamorano & Hon & $\mathbf{M}$ & Meso America & 20.0 & 6 \\
\hline 61 & FT $83-120$ & Bra & $\mathbf{M}$ & Meso America & 22.2 & 26 \\
\hline 62 & Michelite & US & M & Meso America & 16.4 & 15 \\
\hline
\end{tabular}

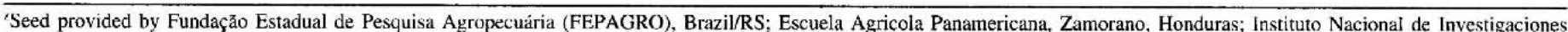

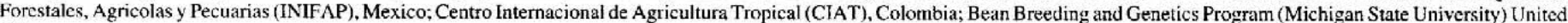
States.

yrigin of cultivars: Bra (Brazil), DR (Dominican Republic). Hon (Honduras), Mex (Mexico), Nth (Netherlands), and US (United States).

${ }^{x}$ Andean (A) and Middle American (M) gene pools of $P$. vulgaris (Singh et al., 1991).

"Races of $P$. vulgaris (Singh et al., 1991).

vSeed weight ( $g / 100$ seeds).

"Resistance index: (total no. of resistance reactions / 34), where 34 was the total no. of races used for inoculation. 
Variability in Uromyces appendiculatus (Pers.:Pers.) Unger (Araya and Steadman, 1998; Sandlin et al., 1996; Martinez et al., 1996; Maclean et al., 1995) and Phaeoisariopsis griseola (Sacc.) Ferraris (Guzman et al., 1995) has been demonstrated to be congruent with diversity present in the Middle American and Andean gene pools of $P$. vulgaris. Coevolution among host and pathogen populations was suggested as the cause of increased levels of the angular leaf spot disease in common bean (Guzman et al., 1995). Reciprocal selection of resistance genes in $P$. vulgaris and virulence genes in $C$. lindemuthianum might also occur (Gepts, 1988). Isolates of $C$. lindemuthianum collected from wild Phaseolus in Latin America showed similar congruence with host gene pools (Sicard et al., 1997). No pattern was observed between host genotypes or geographic origin of 12 isolates of $C$. lindemuthianum from three continents (Fabre et al., 1995). Virulence diversity among 948 isolates $C$. lindemuthianum from 13 Latin American countries formed two groups suggestive of the host gene pools (Pastor-Corrales, 1996), whereas no congruence was observed between host gene pool and reaction of 41 races of C. lindemuthianum to members of the differential series (Balardin et al., 1997). In this study, our objective was to determine if congruency exists between the genetic diversity present in cultivated $P$. vulgaris and the race variability in $C$. lindemuthianum. A diverse group of traditional and modern cultivars of $P$. vulgaris from South, Central and North America were challenged with a large collection of races from the same countries. Virulence tests and multivariate analyses were used to examine the relationship of the $P$. vulgaris gene pool on the population structure of the anthracnose pathogen and the reciprocal relationship of the pathogen on the same host cultivars. Based on these findings, breeding strategies to improve durable resistance to $C$. lindemuthianum are discussed.

\section{Materials and Methods}

Phaseolus vulgaris GERMPLASM AND Colletotrichum lindemuthianum RACEs. In total, 62 P. vulgaris genotypes were inoculated with 34 C. lindemuthianum races. Genotypes were divided into two groups: a) 50 traditional landrace and contemporary cultivars from Brazil, the Dominican Republic, Honduras, Mexico, the Netherlands, and the United States, and b) the 12 anthracnose differential genotypes (Pastor-Corrales, 1991) that were used as controls to confirm race identity. The gene pool origin of all genotypes was inferred based on previous knowledge of host cultivars. Identification, origin, and characteristics of the genotypes are shown in Table 1 . The $34 \mathrm{C}$. lindemuthianum races were identified from isolates collected in Argentina, Brazil, Colombia, Costa Rica, the Dominican Republic, Honduras, Mexico, Peru, and the United States. Isolates were previously characterized as races (Balardin et al., 1997) and classified as either Middle American or Andean race, depending on the gene pool of the host cultivar from which each was isolated. Identification, reaction group and origin of all races are shown in Table 2.

Determination OF GENOTYPE REACTION. Colletotrichum lindemuthianum 'inoculum was increased on modified Mathur's culture medium. The culture medium was prepared with dextrose $\left(8 \mathrm{~g} \cdot \mathrm{L}^{-1}\right), \mathrm{MgSO}_{4} .7 \mathrm{H}_{2} \mathrm{O}\left(2.5 \mathrm{~g} \cdot \mathrm{L}^{-1}\right), \mathrm{KH}_{2} \mathrm{PO}_{4}\left(2.7 \mathrm{~g} \cdot \mathrm{L}^{-1}\right)$, neopeptone $\left(2.4 \mathrm{~g} \cdot \mathrm{L}^{-1}\right)$, yeast extract $\left(2.0 \mathrm{~g} \cdot \mathrm{L}^{-1}\right)$, and agar $\left(16 \mathrm{~g} \cdot \mathrm{L}^{-1}\right)$. Spore suspension was prepared from purified single-conidial isolates by flooding plates with $5 \mathrm{~mL}$ of $0.01 \%$ Tween 80 in distilled water. After scraping the culture surface with a spatula, the dislodged spores were filtered through cheesecloth. Spore concentration was adjusted to $1.0 \times 10^{6} \mathrm{spores} / \mathrm{mL}$ using a hemocytometer.
Seeds for each of the $62 P$. vulgaris genotypes were planted in flat containing Baccto planting mix (Michigan Peat Co., Houston, Texas), and grown under greenhouse conditions (16-h day length at $25^{\circ} \mathrm{C}$ ), for 7 to $10 \mathrm{~d}$ until seedlings had reached the full expanded primary leaf stage. Six seedlings were spray-inoculated with the standardized spore suspension until runoff on the stem and both surfaces of the unifoliolate leaves. After inoculation, plants were maintained in high humidity ( $>95 \%$ ) for $48 \mathrm{~h}$ at 22 to $25^{\circ} \mathrm{C}$. Plants were allowed to dry and were then transferred to greenhouse benches for $5 \mathrm{~d}$. Disease reaction was rated $7 \mathrm{~d}$ after inoculation based on a 1 to 9 severity scale (Balardin et al., 1990). Plants with no visible disease symptoms or with only a few, very small lesions mostly on primary leaf veins were recorded as resistant (scale 1 to $3)$. Plants with numerous small or enlarged lesions, or with sunken cankers on both the lower sides of leaves and the seedling stem, were recorded as susceptible (scale 7 to 9). A severity value for each genotype was calculated as the mean score of six plants. Intermediate values (3.1-6.9) were considered as susceptible for the purpose of this work.

Data ANALYSIS. A resistance index (RI) of each genotype was computed by dividing the number of genotypes that exhibited a resistance reaction by 34 , the total number of races used for inoculation. A virulence index (VI) for each $C$. lindemuthianum race was computed by dividing the number of genotypes with a susceptible reaction by 62 , the total number of inoculated genotypes (15 Andean genotypes, 47 Middle American genotypes).

The principal component analysis was used to derive the variance from severity data associated with the first three principal components. A correlation matrix of severity data obtained from inoculation of 34 races of $C$. lindemuthianum on 62 genotypes was computed by the INTERVAL program in the Numerical Taxonomy and Multivariate Analysis System for personal computer (NTSYS-pc) version 1.70 (Exeter Software, Setauket, N.Y.). The eigenvalue and eigenvector matrices were derived from the correlation matrix by the EIGENVECTOR program (NTSYS-pc). The PROJECTION program (NTSYS-pc) projected $t$ severity data from the severity data matrix onto $k=3$ axes to express the coordinate of each severity data relative to the axes. The MXPLOT and MOD-3D programs (NTSYS-pc) were used to generate the three-dimensional graphics.

The phenetic analysis of virulence data was based on a data matrix generated by scoring resistant reaction as 0 , and susceptible reactions as 1 . Similarity matrices for virulence data were derived using the similarity for genetic data in the SIMGEN program (NTSYS-pc). Genetic differences between individuals within both $P$. vulgaris and $C$. lindemuthianum populations were calculated using the NEI72 coefficient. Polymorphisms were related to both the accumulated number of gene differences per locus and the proportion of common genes among individuals within populations (Nei, 1972). The simple matching similarity coefficients were used to cluster individuals using the SAHN procedure of NTSYS which uses the unweighted pair group method with arithmetic averages (UPGMA). Phenograms for virulence data were produced using the TREE DISPLAY program (NTSYS-pc).

\section{Results}

The RI of the 15 Andean genotypes ranged from $0 \%$ to $82 \%$, whereas the 47 Middle American genotypes ranged from $3 \%$ to $100 \%$ (Table 1). The most susceptible genotypes within the Andean germplasm were Isabella kidney bean and the two cranberry cultivars, Cardinal and Taylor Horticultural. The differential cultivar, Kaboon, was the most resistant $(79 \%)$ followed by the 
kidney bean cultivar, Isles. Greater levels of resistance (>90\%) were present in the Middle American germplasm, many of which were members of the differential series or breeding lines derived from these same differentials. The most susceptible genotypes were the two traditional Honduran red bean cultivars, Zamorano and Desarrural, whereas Michelite, the least resistant genotype in the differential series, showed more resistance $(15 \%)$. As expected, the seed size of the Andean genotypes was larger than that of the Middle American genotypes.

Andean races of $C$. lindemuthianum exhibited higher levels of virulence (VI $=53 \%$ to $100 \%)$ on Andean germplasm than on Middle American germplasm (19\% to 62\%; Table 2). Andean races 39,47 , and 55, highly virulent to Andean genotypes (100\%), exhibited lower virulence to Middle American genotypes, whereas races 15 and 23 (delta) were highly virulent to Andean and Middle
American germplasm $(>60 \%)$. In general, Middle American races of the pathogen exhibited similar virulence indexes on Andean (55\%) and Middle American (60\%) germplasm. Races 31 (kappa) and 87 , however, were highly virulent to Andean germplasm $(87 \%)$ and differentials $(67 \%)$ and less virulent to Middle American differentials ( $33 \%$ ). In contrast, races $449,457,521,1673$, and 1993 from Honduras and Mexico exhibited a low virulence index $(0 \%)$ on Andean differentials and were highly virulent to all Middle American genotypes ( $40 \%$ to $94 \%$ ). Race 2047 was highly virulent to all germplasm ( $>89 \%$ ), regardless of origin. Increased levels of disease in host-pathogen interactions within a gene pool were common.

Principal component analysis of the disease reaction of $62 P$. vulgaris genotypes inoculated with $34 \mathrm{C}$. lindemuthianum races grouped the genotypes on the basis of host gene pool. Within each

Table 2. Identification, origin, reaction group, and virulence index of 34 races of Colletotrichum lindemuthianum

\begin{tabular}{|c|c|c|c|c|c|c|c|c|c|c|c|}
\hline & & & \multicolumn{9}{|c|}{ Virulence index ${ }^{2}$} \\
\hline \multicolumn{3}{|c|}{$\operatorname{Race}^{y}$} & \multicolumn{4}{|c|}{ Germplasm } & \multicolumn{4}{|c|}{ Differentials } & \multirow{2}{*}{$\frac{\text { Total }}{\%}$} \\
\hline Identification & Origin & RG & A & $\%$ & MA & $\%$ & $\mathrm{~A}$ & $\%$ & MA & $\%$ & \\
\hline 2 & Mexico & $\mathrm{A}$ & 9 & 60 & 8 & 17 & 1 & 33 & 0 & 0 & 27 \\
\hline 3 & Peru & A & 11 & 73 & 12 & 26 & 1 & 33 & 1 & 11 & 37 \\
\hline 5 & Peru & A & 8 & 53 & 10 & 21 & 1 & 33 & 1 & 11 & 29 \\
\hline 7 & United States & A & 12 & 80 & 16 & 34 & 2 & 67 & 1 & 11 & 45 \\
\hline 15 & Colombia & A & 13 & 87 & 29 & 62 & 2 & 67 & 2 & 22 & 68 \\
\hline 19 & Dominican Republic & A & 9 & 60 & 13 & 28 & 1 & 100 & 2 & 22 & 35 \\
\hline 23 & United States & $\Lambda$ & 12 & 80 & 28 & 60 & 2 & 67 & 2 & 22 & 65 \\
\hline 38 & Dominican Republic & A & 14 & 93 & 13 & 28 & 3 & 100 & 0 & 0 & 44 \\
\hline 39 & Dominican Republic & A & 15 & 100 & 20 & 43 & 3 & 100 & 1 & 11 & 56 \\
\hline 47 & Dominican Republic & A & 15 & 100 & 17 & 36 & 3 & 100 & 2 & 22 & 52 \\
\hline $\mathbf{5 5}$ & Dominican Republic & A & 15 & 100 & 10 & 21 & 3 & 100 & 2 & 22 & 40 \\
\hline 102 & United States & A & 11 & 73 & 8 & 17 & 3 & 100 & 1 & 11 & 31 \\
\hline 130 & United States & A & 10 & 67 & 9 & 19 & 1 & 33 & 1 & 11 & 31 \\
\hline 1 & Brazil & MA & 4 & 27 & 19 & 40 & 0 & 0 & 1 & 11 & 37 \\
\hline 8 & Peru & MA & 8 & 53 & 18 & 38 & 0 & 0 & 1 & 11 & 42 \\
\hline 9 & Honduras & MA & 6 & 40 & 25 & 53 & 0 & 0 & 2 & 22 & 50 \\
\hline 17 & Brazil & MA & 8 & 53 & 28 & 60 & 0 & 0 & 2 & 22 & 58 \\
\hline 31 & Brazil & MA & 13 & 87 & 27 & 57 & 2 & 67 & 3 & 33 & 65 \\
\hline 65 & United States & MA & 8 & 53 & 31 & 66 & 0 & 0 & 2 & 22 & 63 \\
\hline 73 & United States & MA & 7 & 47 & 25 & 53 & 0 & 0 & 3 & 33 & 52 \\
\hline 81 & Argentina & MA & 2 & 13 & 17 & 36 & 0 & 0 & 3 & 33 & 31 \\
\hline 87 & Brazil & MA & 14 & 93 & 33 & 70 & 2 & 67 & 3 & 33 & 76 \\
\hline 89 & Brazil & MA & 7 & 47 & 27 & 57 & 0 & 0 & 3 & 33 & 55 \\
\hline 257 & Mexico & MA & 8 & 53 & 27 & 57 & 0 & 0 & 2 & 22 & 56 \\
\hline 321 & Mexico & MA & 7 & 47 & 27 & 57 & 0 & 0 & 3 & 33 & 55 \\
\hline 337 & Brazil & MA & 10 & 67 & 28 & 60 & 0 & 0 & 4 & 44 & 61 \\
\hline 357 & Mexico & MA & 12 & 80 & 32 & 67 & 1 & 33 & 4 & 44 & 71 \\
\hline 453 & Brazil & MA & 10 & 67 & 34 & 72 & 1 & 33 & 4 & 44 & 71 \\
\hline 449 & Mexico & MA & 8 & 51 & 35 & 74 & 0 & 0 & 4 & 44 & 68 \\
\hline 457 & Mexico & MA & 8 & 51 & 31 & 67 & 0 & 0 & 5 & 56 & 63 \\
\hline 521 & Honduras & MA & 6 & 40 & 19 & 40 & 0 & 0 & 3 & 34 & 40 \\
\hline 1673 & Honduras & MA & 6 & 40 & 28 & 59 & 0 & 0 & 5 & 56 & 54 \\
\hline 1993 & Honduras & MA & 9 & 60 & 44 & 94 & 0 & 0 & 7 & 78 & 85 \\
\hline 2047 & Costa Rica & MA & 15 & 100 & 45 & 96 & 3 & 100 & 8 & 89 & 97 \\
\hline
\end{tabular}

${ }^{7}$ Germplasm virulence index of Andean (A) germplasm = total no. of A susceptible genotypes/15 A genotypes (Table 1). Germplasm virulence index of Middle American (MA) germplasm = total no. of MA susceptible genotypes/47 MA genotypes (Table 1). Differential virulence index of A differential genotypes = total no. of A susceptible differentials/3 A differential genotypes. Differential virulence index of MA differential genotypes $=$ total no. of MA susceptible differentials/9 MA differential genotypes. Total virulence index = total no. of susceptible genotypes/62 genotypes.

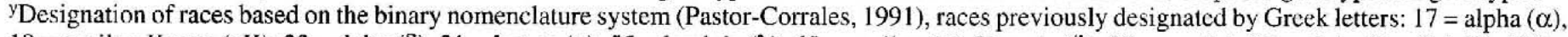
$19=$ epsilon Kenya $(\varepsilon K), 23=$ delta $(\delta), 31=\operatorname{kappa}(\kappa), 55=$ lambda $(\lambda), 65=\operatorname{epsilon}(\varepsilon), 81=$ eta $(\xi), 87=$ mu $(\mu), 89=$ alpha-Brazil $(\alpha B), 102=$ gamma $(\gamma), 130=$ beta $(\beta)$, and $453=$ zeta $(\zeta)$ (Balardin and Kelly, 1997). RG = reaction group: Andean (A) and Middle American (MA) races classified according to the gene pool of the host. 


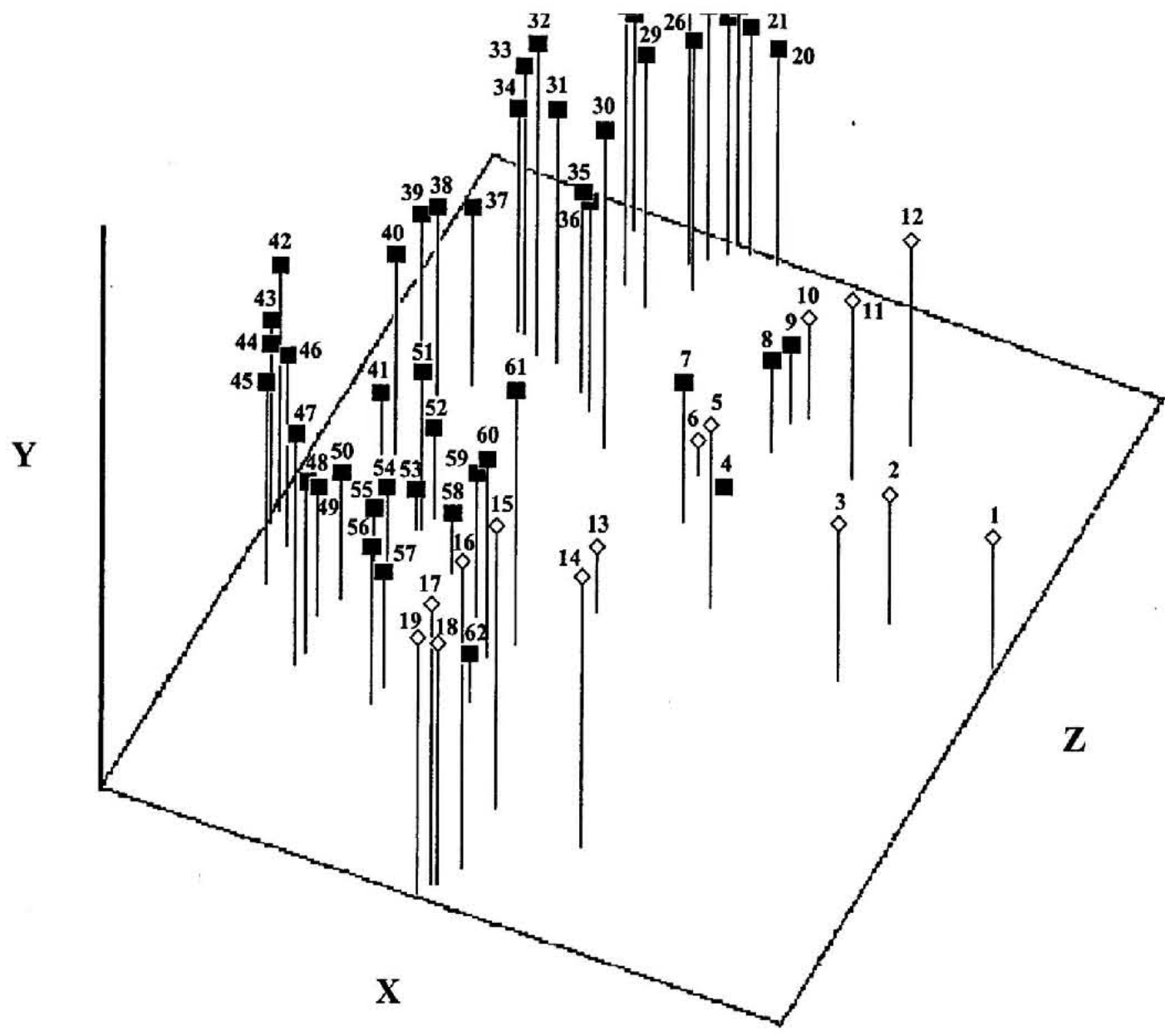

Fig. 1 (above). Three-dimensional association between 62 Phaseolus vulgaris genotypes based on the first three principal components from multivariate analysis of severity data after inoculation with 34 Colletotrichum lindemuthianum races. The $\mathrm{X}, \mathrm{Y}$, and $\mathrm{Z}$ axes are the first, second, and third principal components, respectively. $\mathbf{D}=$ Middle American genotypes, $\hat{\nu}=$ Andean genotypes. Genotypes (see Table 1) were grouped within clusters (A) 1-12, (B) 13-19, (C) 20-36, and (D) $37-62$. cultivars Isles and Red Hawk, bred for resistance to anthracnose. The Middle American cultivars incluster A were located towards the more resistant Middle American members of cluster $\mathrm{C}$. These included the Michigan navy bean cultivar Seafarer, the European garden bean cultivar Widusa (a member of the differential series), and the two Mexican cultivars Pinto Villa and Bayo Victoria. The average resistance index of germplasm within cluster A was $55 \%$ (Table 1). Only Andean genotypes were observed in cluster B. These included the highly susceptible kidney and cranberry

Fig. 2 (below). Three-dimensional association among 34 Colletotrichum lindemuthianum races based on the first three principal components from multivariate analysis of severity data after inocluation on 62 Phaseolus vulgaris genotypes. The $\mathrm{X}, \mathrm{Y}$, and $\mathrm{Z}$ axes are the first, second, and third principal components, respectively. $\mathbf{\square}=$ Middle American genotypes, $\widehat{\diamond}=$ Andean genotypes. Arg = Argentina, $\mathrm{Bra}=$ Brazil, $\mathrm{Cl} b=$ Colombia, $\mathrm{CR}=$ Costa Rica, DR = Dominican Republic, Hon $=$ Honduras, Mex $=$ Mexico, Per $=$ Peru, US $=$ United States. Races grouped in clusters: $(\mathbf{A}) 1673 \mathrm{Hon}, 521 \mathrm{Hon}$, IBra, 89Bra, 457Mex, 453Bra, 257Mex, 9Hon, 357Mex, 2047CR, 321 Mex, $65 \mathrm{US}$, 73US, 449Mex, and 1993Hon; (B) $17 \mathrm{Bra}, 337 \mathrm{Bra}, 87 \mathrm{Bra}, 337 \mathrm{Mex}$, $31 \mathrm{Bra}, 15 \mathrm{Clb}$, and 23US; (C) 5Per, 7US, 3Per, 2Mex, 130US, 102US, 55DR, and 19DR; (D) 39DR, 38DR, and 47DR. Outliers (A-C) 8 Per and 81 Arg. gene pool there was a further subgrouping of genotypes according to their overall resistance levels to the 34 races of $C$. lindemuthinaum (Fig. 1). Four distinct clusters were observed. Cluster A (genotypes 1-12, Table 1) was the most diffuse and included genotypes from both gene pools, although the majority of genotypes were from the Andean gene pool. Cluster B consisted of genotypes (13-19) exclusively from Andean origin, whereas clusters C (genotypes 20-36) and D (genotypes 37-62) were comprised of genotypes from the Middle American gene pool. The first three principal component axes accounted for $\approx 30 \%$ of the total variation within the $34 \times 34$ distance matrix.

In cluster A, Andean genotypes included three members of the differential series, Michigan Dark Red Kidney (MDRK), Perry Marrow and Kaboon, along with three contemporary cultivars, Montcalm, PC-50 and Charlevoix, and two new dark red kidney

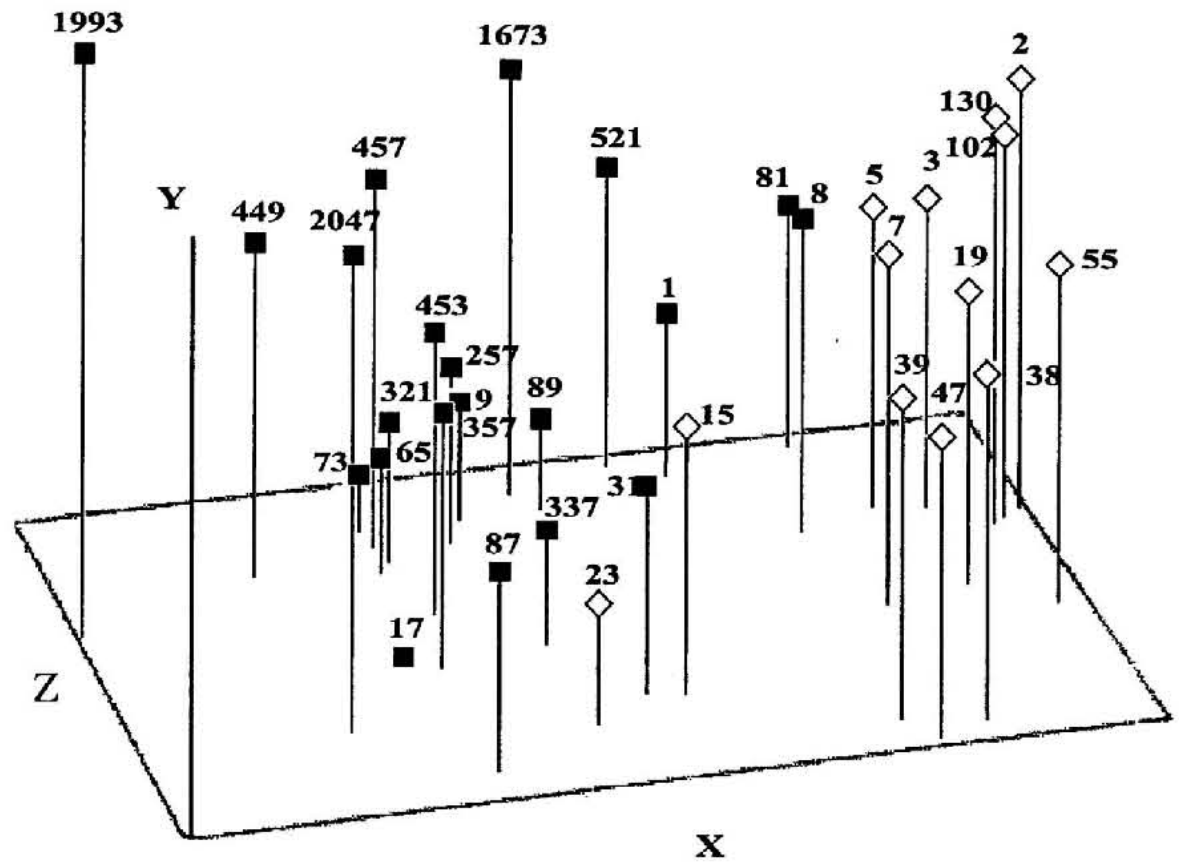

J. AMER. SOC. Hor'T. Scl. 123(6):1038-1047. 1998. 
bean cultivars, Isabella, Ruddy, Taylor Horticultural and Cardinal from the United States, and Cacahuate 72 (cranberry), Chihuahua 21 and Bayomex from Mexico. Genotypes in this cluster exhibited a $6 \%$ level of resistance (Table 1). The cultivar Michelite (\#62) may appear to be in this cluster but since it lies in a lower plane, it was placed in cluster D. Cluster $\mathrm{C}$ was formed exclusively by Middle American genotypes that were either members of the differential series or contemporary cultivars bred for resistance to anthracnose. Genotypes G 2333, AB 136, TO, TU, PI 207262, and Cornell 49242, members of the differential series, fell within this cluster. Germplasm within cluster C exhibited a $78 \%$ level of resistance (Table 1). The breeding lines SEL 1308 and SEL 1360 derived from G2333, BAT 93 derived fromPI 207262 and Catrachita derived from $\mathrm{AB} 136$ all grouped in this cluster and showed resistance levels over $80 \%$. Cluster $\mathrm{D}$ was formed by Middle American genotypes, which were either the most susceptible members of the differential series (e.g., Michelite, Mexico 222), older landraces or traditional and modern cultivars bred for characteristics other than anthracnose resistance. Genotypes in cluster $\mathrm{D}$ showed a mean level of resistance of $30 \%$ (Table 1). Present in this group were traditional cultivars such as Danli 46, Desarrural IR, and Zamorano from Honduras, Carioca and Rio Tibagi from Brazil, and T-39 and C-20 from the United States.

The principal component analysis of the 34 C. lindemuthianum races inoculated onto 62 genotypes is shown in Fig. 2. The first three principal component axes accounted for $\approx 20 \%$ of the total variation within the $62 \times 62$ distance matrix. Four distinct clusters were observed. Clusters A was comprised of Middle American races 1, 89, and 453 from Brazil; 2047 from Costa Rica; 9, 521, 1673, and 1993 from Honduras; 257, 321, 357, 449, and 457 from Mexico; and 65 and 73 from the United States. Cluster B showed a predominance of Middle American races 17, 31, 87, and 337 from Brazil; in addition to the Andean races 15 and 23 from Colombia and the United States, respectively. In contrast, cluster $\mathrm{C}$ showed a predominance of Andean races 19 and 55 from the Dominican Republic; 2 from Mexico; 3 and 5 from Peru. Middle American races 8 from Peru and 81 from Argentina fell between clusters A and C. Cluster D consisted of Andean races 38,39 , and 47 exclusively from the Dominican Republic. The average virulence indexes of races within clusters A, B, C, and D was $55 \%, 70 \%, 35 \%$, and $51 \%$, respectively (Table 2). In cluster A, no race was virulent to any Andean resistance source present in the differential series. However, these races showed $41 \%$ of virulence on Andean germplasm from the Dominican Republic, Mexico and the United States. Races within clusters B and $\mathrm{C}$ were virulent to resistance sources from both gene pools. Races from these groups showed a wide range in virulence $(53 \%$ to $100 \%$ ) on all genotypes. In cluster D, races 38 , 39 , and 47 were virulent to all Andean sources present in the differential series. Races from Honduras showed only a Middle American reaction, whereas races from the Dominican Republic showed only an Andean reaction.
Races from Brazil, Mexico, Peru, and the United States were virulent to genotypes from both gene pools.

Phenetic analysis of the host germplasm formed three clusters (Fig. 3). In cluster I Middle American genotypes predominated, but two subgroups of Andean genotypes were also observed. Genotypes within cluster I corresponded to those with the lowest level of resistance observed in clusters B and D (Fig. 1). Andean cultivars Montcalm, Red Hawk, Charlevoix, and the Middle American cultivar Seafarer, which corresponded to the highest resistance level within cluster A, were the exceptions (Fig. 1). Likewise, cultivars Cornell 49242, Blackhawk, Zacatecas, Negro 150 and FM M38 with high levels of resistance grouped in the same region of cluster I. Andean germplasm predominated in cluster II. Interestingly, the highly resistant Middle American breeding lines SEL 1308 and SEL 1360 grouped with the Andean genotype MDRK. In addition, cultivars Bayo Victoria, Pinto Villa and Widusa were placed in cluster II. Although, these cultivars exhibit characteristics of Middle American germplasm, they possess

Fig. 3. Phenogram of 62 Phaseolus vulgaris genotypes based on virulence data obtained from the inoculation of 34 Colletotrichum lindemuthianum races. The NEI72 coefficient (SIMGEN-NTSYS-pc) generated a similarity matrix of virulence data. The SAHN program (NTSYS-pc) estimated the genetic distance using UPGMA. Numbers in parentheses after each genotype refer to position in Table 1.

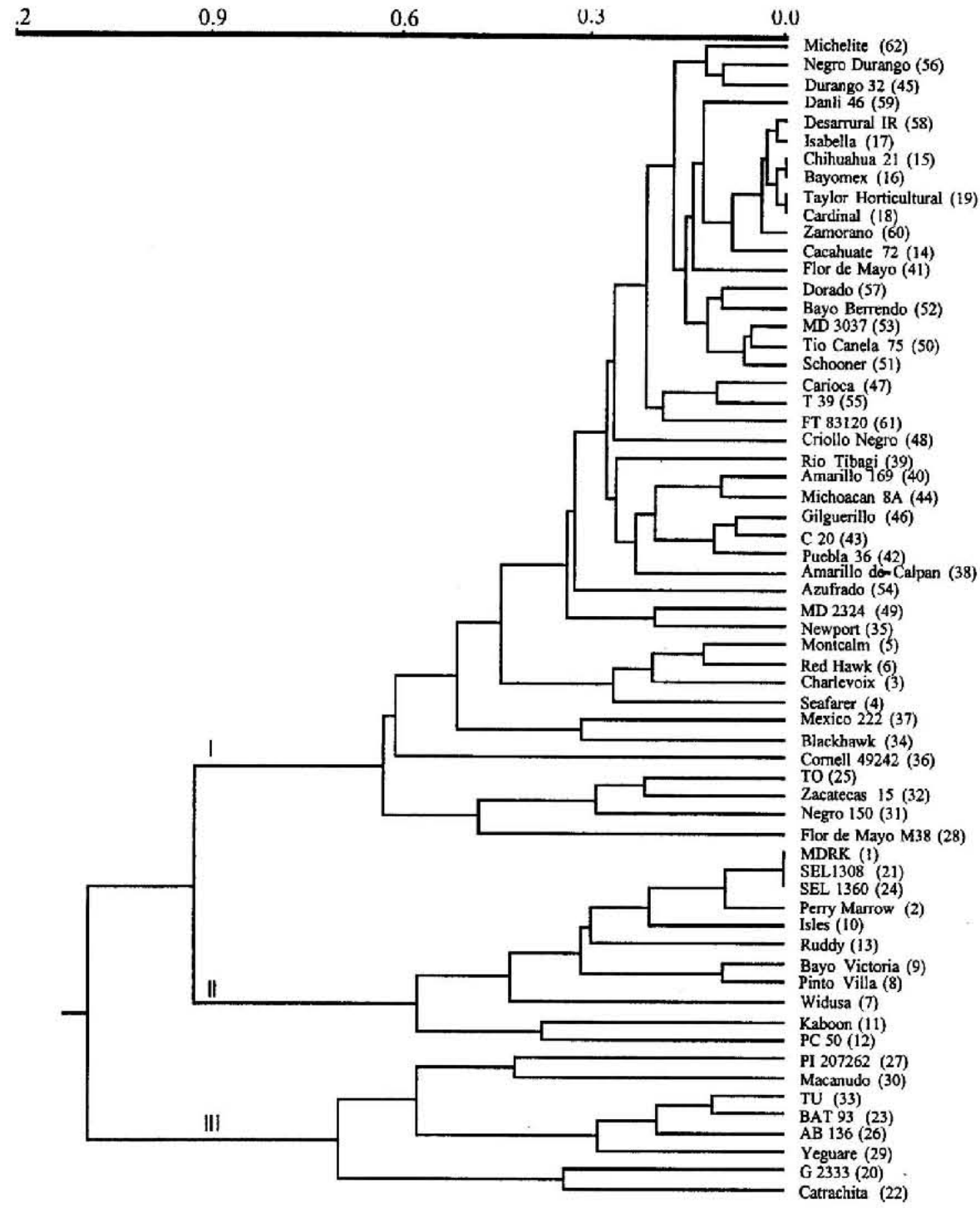


resistance genes derived from Andean sources. Genotypes in cluster III consisted of the highly resistant Middle American differentials and breeding lines derived from these resistance sources.

Two major clusters of races corresponding to the Andean and Middle American reaction groups were observed in Fig. 4. Clusters I and II were $68 \%$ dissimilar. In cluster I, Middle American races predominated but included the Andean races 15 and 23 from cluster B. Cluster II was formed exclusively of Andean races. The phenetic analysis showed congruence with some sub-clusters in the principal component analyses. Races 38,39 , and 47 from the Dominican Republic showed a tight cluster in both analyses. Races $31,87,23$, and 15 , which formed a tight subcluster in cluster B (Fig. 2 ), showed $88 \%$ similarity in the phenetic analyses. In contrast, Middle American races 8 and 81 which were outliers falling between the predominant Middle American clusters A and Andean cluster C (Fig. 2) clustered with Middle American races in cluster I, but adjacent to the Andean cluster II (Fig. 4). Congruence of the 34 races with the two $P$. vulgaris gene pools was supported by the multivariate analyses.

\section{Discussion}

Diverse sources of Phaseolus vulgaris germplasm, from Brazil, the Dominican Republic, Honduras, Mexico, the Netherlands, and the United States demonstrated a reciprocal influence on the variability present in 34 races of $C$. lindemuthianum in our study. Genotypes known to carry different genes conditioning resistance to anthracnose, were grouped by multivariate analyses on the basis of gene pool (Andean and Middle American). Within each gene pool, genotypes were grouped according to their overall resistance levels to C. lindemuthianum. Cluster A was the most interesting since it contained genotypes from both gene pools (Fig. 1). Among the Andean genotypes were members of the differential series such as MDRK, Perry Marrow and Kaboon, the cultivar Charlevoix, bred for resistance to the Andean race 130 (Andersen et al., 1963) and Montcalm, known to carry the same $\mathrm{Co}-1$ gene as MDRK (Young and Kelly, 1996a, 1996b). In addition, Isles (Kelly et al., 1994) and Red Hawk (Kelly et al., 1998), bred to possess the Co- $\mathrm{I}$ and $\mathrm{Co}-2$ genes, were present. No information on the other Andean cultivar, PC-50 from the Dominican Republic was available. However, its presence within cluster A would suggest that it possesses similar high levels of resistance as the other genotypes in cluster A compared to the susceptible Andean germplasm in cluster B. Four Middle
American cultivars were present in cluster A. These included Seafarer, known to possess the Andean $\mathrm{Co}-1$ gene (Young and Kelly, 1996b); Widusa, previously classificd as being of Andean origin (Sicard et al., 1997); and the Mexican cultivars Pinto Villa and Bayo Victoria, reported to carry anthracnose resistance genes from the Andean parent Canario 101 (Acosta-Gallegos et al. 1995). It would appear that cluster A is comprised of Andean resistance genes regardless of whether they are present in Andean cultivars or have been introgressed into Middle American cultivars. Cluster B was comprised of highly susceptible Andean cranberry genotypes such as Taylor Horticultural and Cardinal cranberry beans from the United States, and Cacahuate 72 from Mexico and the U.S. kidney bean Isabella. Isabella, however, does not possess the $\mathrm{Co}-1$ gene present in other kidney bean cultivars such as Montcalm, MDRK and Charlevoix (Young and Kelly, 1996b). Known genetic differences between genotypes were supported by the principal component analysis in our study.

Middle American genotypes with known sources of resistance and cultivars bred for resistance to $C$. lindemuthianum predomi-

Fig. 4. Phenogram of 34 Colletotrichum lindemuthianum races based on virulence data obtained from the inoculation on 62 Phaseolus vulgaris genotypes. The NEI72 coefficient (SIMGEN-NTSYS-pc) generated a similarity matrix of virulence data. The SAHN program (NTSYS-pc) estimated the genetic distance using UPGMA. The binary identification of Colletotrichum lindemuthianum races (Pastor-Corrales, 1991) is followed by the origin of isolates Arg = Argentina, $\mathrm{Bra}=$ Brazil, $\mathrm{Clb}=$ Colombia, $\mathrm{CR}=$ Costa Rica, $\mathrm{DR}=$ Dominican Republic, Hon $=$ Honduras, Per $=$ Peru, Mex $=$ Mexico, and US $=$ United States.

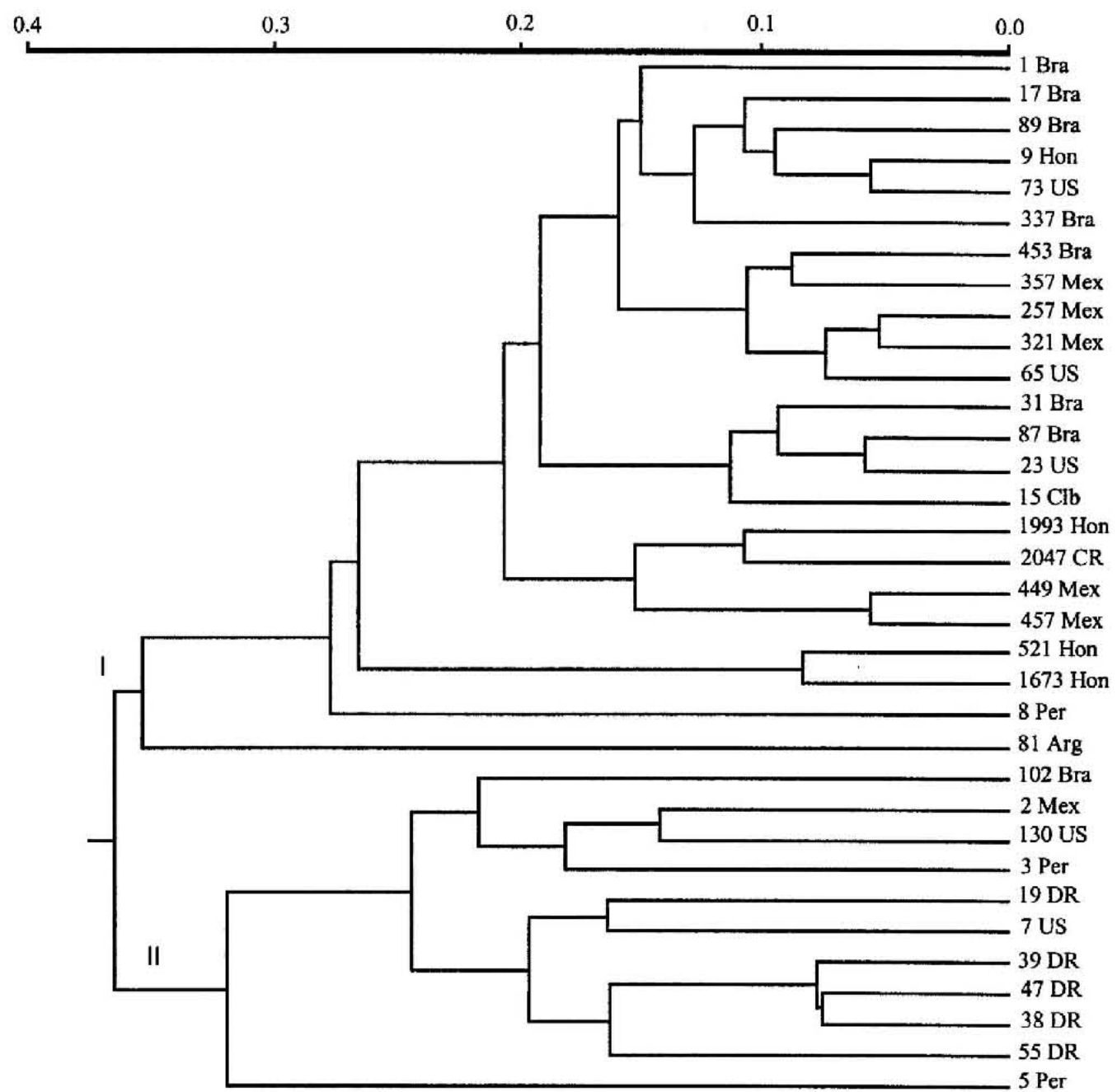


nated in cluster $\mathrm{C}$. In contrast, the Middle American genotypes in cluster D are older landraces, traditional cultivars or modern cultivars bred for characteristics other than for anthracnose resistance. For instance, a number of cultivars from Honduras, such as Tio Canela 75, Dorado, MD2324, and MD 3037, bred primarily for resistance to Bean Golden Mosaic Virus (Rosas et al., 1997) grouped in cluster D. In contrast, related Honduran cultivars Yeguare and Catrachita, bred for resistance to $C$. lindemuthianum grouped in cluster C (Young and Kelly, 1996a). Two members of the differential series fell in cluster D, Michelite the universal susceptible cultivar, and Mexico 222 (source of $\mathrm{Co}-3$ gene) recognized for its limited resistance to $C$. lindemuthianum (Menezes and Dianese, 1988; Pastor-Corrales et al., 1995; Rava et al., 1993; Restrepo, 1994; Rodriguez, 1991). Other cultivars clustering in cluster D included Carioca and Rio Tibagi, the most widely grown cultivars in Brazil (Voysest et al., 1994), a number of Mexican cultivars not recognized as possessing resistance to anthracnose, the susceptible landrace cultivar Zamorano from Honduras and the cultivars Schooner and C-20 from the United States bred for high yield (Kelly et al., 1984).

The phenetic analysis showed that both cultivars and races grouped congruently to the $P$. vulgaris gene pools, and subgroups of genotypes with similar overall resistance were observed (Figs. 3 and 4). No grouping was observed for germplasm based on geographic origin. Since only a few sources have been used in breeding for resistance to C. lindemuthinaum, groups of genotypes possessing similar resistance genes were observed. For instance, cultivars Charlevoix, Seafarer, Montcalm and Red Hawk known to possess the $\mathrm{Co}-1$ resistance gene, grouped in cluster $\mathrm{l}$. In contrast, cultivars Isabella, Chihuahua 21, Bayomex, Taylor Horticultural and Cardinal with no known resistance genes grouped in a different cluster.

Genetic diversity among genotypes with resistance to $C$. lindemuthianum was greater than that observed among genotypes with no resistance to the pathogen (Fig. 3). Large genetic distances were observed among clusters. Genotypes with high overall resistance grouped in clusters II and III. In cluster II resistance from Andean sources predominated, despite the gene pool of the genotypes. For instance, the resistance to $C$. lindemuthianum present in the cultivars Seafarer, Pinto Villa and Widusa is from Andean sources despite the fact these cultivars are from the Middle American gene pool. Cluster III showed the largest genetic dissimilarity in relation to the other clusters.

Congruence among other bean pathogens and host gene pools has been reported (Araya and Steadman, 1998; Guzman et al., 1995; Maclean et al., 1995; Martinez et al., 1996; Sandlin et al., 1996). In all cases, pathogens were divided into two groups corresponding to the Middle American or Andean gene pools. Phenetic analysis (Fig. 4) indicated that virulence factors might have been selected according to the predominant host gene pool within each country. Selection of specific virulence factors in Honduras and the Dominican Republic resulted in the predominance of Middle American and Andean races in each country, respectively (Table 2 ). For instance, races from Honduras overcame no Andean resistance genes present in the differential series, whereas races 38, 39, 47, and 55 from the Dominican Republic overcame all Andean resistance sources present in the differential series. Germplasm grown in Mexico and the United States belongs to both gene pools. Races from these countries overcame resistance sources from both the Andean and Middle American gene pools (Table 2). These races were observed in all but cluster D (Fig. 2). In contrast, germplasm grown in Brazil belongs mostly to the Middle American gene pool (Voysest et al., 1994). Nevertheless, races carrying virulence factors to both host gene pools have been reported in Brazil (Meneses and Dianese, 1988; Balardin et al., 1990). For instance, races 31,55 , and 87 overcame Andean resistance sources present in MDRK and Perry Marrow. In addition, Andean race 55 also overcame the highly resistant Andean cultivar Kaboon. Pathogen variability in Brazil was confirmed by the grouping of races within cluster A (race 1), cluster B (races 31 and 87 ), and cluster $C$ (races 55, 102, and 130; Fig. 2).

The Andean races 15 and 23 consistently clustered among Middle American races in cluster B (Fig. 2) and cluster I (Fig. 4). In contrast, race 8 , from the Andean region and virulent to the Middle American $\mathrm{Co}$-2 gene, clustered along with Andean races in cluster C (Fig. 2) and with the Middle American races in cluster I (Fig. 4). These results suggest the presence of both Middle American and Andean virulence factors within these races. Similarly, in Brazil, races 31 and 87 , virulent to the Andean resistance sources Co- 1 and Perry Marrow, have been isolated consistently from Middle American hosts (Menezes and Dianese, 1988; Balardin et al., 1990). Nevertheless, these races were grouped along with Andean races 15 and 23 in cluster B (Fig. 2) and showed high similarity with the same races in cluster I (Fig. 4). Therefore, categorization of races based on origin of isolates and virulence could be biased if broader virulence is the result of adaptation of some $C$. lindemuthianum races to both host gene pools.

Clusters based on the virulence data showed no agreement with clusters based on internal transcribed spacer (ITS) sequence data for the same races (Balardin et al., 1998). Race 38 from the Dominican Republic clustered with race 457 from Mexico and race 23 from the United States according to ITS sequence data but no relationship was observed between these races based on virulence. A lack of agreement between virulence and sequence data was observed for a second group of races, 81 from Argentina, 15 from Colombia, and 5 from Peru, identified as possessing similar ITS sequences (Balardin et al., 1998). The differences in genetic variability detected by these analyses suggests that polymorphism in the ITS region is not linked to specific virulence phenotypes in C. lindemuthianum. Based on our virulence data, the 34 races effectively identified the presence of resistance genes regardless of the genetic origin of the host. The clusters generated by the multivariate analysis, suggested congruency between pathogen variability and host diversity.

IMPLICATIONS FOR RESISTANCE BREEIING. In our study, all host resistance sources except G2333 were defeated by at least one race of $C$. lindemuthianum. The broader genetic resistance present in G2333 has been attributed to the combination of three resistance genes $\mathrm{Co}-4^{2}, \mathrm{Co}-5$, and $\mathrm{Co}-7$ (Young et al., 1998). Previous work based on virulence analysis of variability in $C$. lindemuthianum showed no clustering of races according to the host gene pools of the 12 differential cultivars (Balardin et al., 1997). In this study a more comprehensive sample of host genotypes was successfully used to identify more pathogen variability based on virulence data. Divergence of pathogenic virulence in $C$. lindemuthianum is believed to correspond with divergence in the host gene pools (Gepts, 1988). The diversity among isolates collected from wild Phaseolus in Latin America is further evidence for coevolution between $C$. lindemuthianum and $P$. vulgaris (Sicard et al., 1997). If coevolution can explain congruence between pathogen variability and host resistance, opportunities arise for pyramiding complementary resistance genes to increase the durability of resistance in cultivars of $P$. vulgaris. For instance, the incorporation of Andean resistance genes into Middle American bean breeding populations in Honduras, or introgressing Middle American resistance genes into Andean genotypes grown in the Dominican Republic should 
result in more durable resistance in each country. The simultaneous production of genotypes from Andean and Middle American gene pools within a single geographic area, might have led to the selection of broader virulence in $C$. lindemuthinaum, where some races are highly virulent on genotypes from both gene pools. In these countries, the deployment of resistance genes based on their complementary action against current races, might be beneficial to counteract the increased pathogen variability. Combining complementary resistance sources present in clusters A and C using genotypes with high RI values is suggested. Rapid progress in breeding for resistance in the Durango race should be possible using, as parents, the Middle American cultivars, Pinto Villa and Bayo Victoria which already possess an Andean resistance gene(s). In the United States, the complementation of the weaker $\mathrm{Co}-1$ and Co-2 genes from both gene pools appears to have been an effective strategy in developing increased levels of resistance in the kidney bean cultivar Isles. Finally, the choice of complementary resistance genes to pyramid will vary by region.

\section{Literature Cited}

Acosta-Gallegos, J.A., R. Ochoa-Márquez, M. . Arrieta-Montiel,. F. Ibarra-Pérez, A.P. Ravelero, and I.S. Valdez. 1995. Registration of 'Pinto Villa' common bean. Crop Sci. 35:1211.

Andersen, A.L., M.W. Adams, and G. Whitford. 1963. Charlevoix anthracnose-resistant dark red kidney bean. Mich. Agr. Expt. Sta. Res. Rpt. $6: 1-3$.

Andrus, C.F. and B.L. Wade. 1942. The factorial interpretation of anthracnose resistance in beans. USDA Tech. Bul, 310. p. 1-29.

Araya, C.M. and J.R. Steadman. 1998. Variation in virulence, telia production, and RAPD patterns among isolates of the bean rust pathogen from the Americas. Annu. Rpt. Bean Improv. Coop. 41:23 24.

Balardin, R.S., A.M. Jarosz, and J.D. Kelly. 1997. Virulence and molecular diversity in Colletotrichum lindemuthianum from South, Central and North America. Phytopathology 87:1184 1191.

Balardin, R.S and J.D. Kelly. 1997. Re-characterization of Colletotrichum lindemuthianum races. Annu. Rpt. Bean Improv. Coop. 40:126-127.

Balardin, R.S., M.A. Pastor-Corrales, and M.M. Otoya. 1990. Variabilidade patogênica de Colletotrichum lindemuthianum no Estado de Santa Catarina. Fitopatol. Bras. 15:243-245.

Balardin, R.S., J.J. Smith, and J.D. Kelly. 1998. Ribosomal DNA polymorphism in Colletotrichum lindemuthianum. Mycol. Res. (in press).

Barrus, M.F. 1918. Varietal susceptibility of beans to strains of Colletotrichum lindemuthianum (Sacc. \& Magn.) B. \& C. Phytopathology 8:589-605.

Blondet, A. 1963. L'anthracnose du haricot: etudé des races physiologiques du Colletotrichum lindemuthianum. PhD thesis, Faculté de Sciense, Paris, France.

Burkholder, W.H. 1923. The gamma strain of Colletotrichum lindemuthianum (Sacc. et Magn.) B. et C. Phytopathology 13:316-323.

Casela, C.R., A.S. Ferreira, K.A. Zeller, and M. Levy. 1995. Pathotype variation in the sorghum anthracnose fungus: a phylogenetic perspective for resistance breeding: Interdisciplinary bridges to improved sorghum and millet crops, p. 257-288. In: J.F. Leslie and R.S. Frederiksen (eds.). Disease analysis through genetics and biotechnology. Iowa State Univ. Press, Ames.

Dillard, H.R. and A.C. Cobb. 1993. Survival of Colletotrichum lindemuthianum in bean debris in New York State. Plant Dis. 77:12331238 .

Duvick, D.N. 1996. Plant breeding, an evolutionary concept. Crop Sci. 36:539-548.

Fabre, J.V., J. Julien, D. Parisot, and M. Dron. 1995. Analysis of diverse isolates of Colletotrichum lindemuthianum infecting common bean using molecular markers. Mycol. Res. 99:429-435.

Fouilloux, G. 1979. New races of bean anthracnose and consequences on our breeding programs, p. 221-235. In: H. Maraite and J.A. Meyer (eds.). Disease of tropical food crops. Louvain-la-Neuve, Belgium.

Garrido, E.R. 1986. Identificación de razas fisiológicas de Colletotrichum lindemuthianum (Sacc. \& Magn.) Scrib. en Mexico y busqueda de resistência genética a este hongo. MS thesis, Institución de Ensenanza y Investigación en Ciencias Agrícolas, Montecillos, Mexico.

Gepts, P. 1988. A Middle American and an Andean common bean gene pool, p. 375-390. In: P. Gepts (ed.). Genetic resources of Phaseolus beans; their maintenance, domestication, and utilization. Kluwer. London.

Guzman, P., M.R. Donado, and G.E. Galvez. 1979. Perdidas economicas causadas por la antracnosis del frijol Phaseolus vulgaris en Colombia. Turrialba 29:65-67.

Guzman, P., R.L. Gilbertson, R. Nodari, W.C. Johnson, S.R. Temple, D. Mandala, A.B.C. Mkandawire, and P. Gepts. 1995. Characterization of variability in the fungus Phaeoisariopsis griseola suggests coevolution with the common bean (Phaseolus vulgaris). Phytopathology 85:600. 607.

Kelly, J.D., M.W. Adams, A.W. Saettler, G.L. Hosfield, and A. Ghaderi. 1984. Registration of C-20 navy bean. Crop Sci. 24:822

Kelly, J.D., L. Afanador, and L.S. Cameron. 1994. New races of Colletotrichum lindemuthianum in Michigan and implications in dry bean resistance breeding. Plant Dis. 78:892-894.

Kelly, J. D., G.L. Hosfield, G.V. Varner, M.A. Uebersax, R.A. Long, and J. Taylor. 1994. Registration of 'Isles' dark red kidney bean. Crop Sci. 34:1407-1408.

Kelly, J.D., G.L. Hosfield, G.V. Varner, M.A. Uebersax, R.A. Long, and J. Taylor. 1998. Registration of 'Red Hawk' dark red kidney bean. Crop Sci. 38:280-281.

Kruger, J., F.M. Hoffmann, and N. Hubbeling. 1977. The kappa race of Colletotrichum lindemuthianum and sources of resistance to anthracnose in Phaseolus beans. Euphytica 26:23-25.

Levy, M., F.J. Correa-Victoria, R.S. Zeigler., S. Xu, and J. Hamer. 1993. Genetic diversity of the rice blast fungus in a disease nursery in Colombia. Phytopathology 83:1427-1433.

Maclean, D.J., K.S. Braithwaite, J.A.G. Irwin, J.M. Manners, and J.V. Groth. 1995. Random amplified polymorphic DNA reveals relationships among diverse genotypes in Australian and American collections of Uromyces appendiculatus. Phytopathology 85:757-765.

Martinez, J.P., J.V Groth, and N.D. Young. 1996. Non-mendelian and skewed segregation of DNA markers in wide crosses of the bean rust fungus Uromyces appendiculatus. Curr. Genet. 29:159-167.

Mastenbroek, C. 1960. A breeding programme for resistance to anthracnose in dry shell haricot beans, based on a new gene. Euphytica 9:177184.

Menezes, J. R. and J.C. Dianese. 1988. Race characterization of Brasilian isolates of Colletotrichum lindemuthianum and detection of resistance to anthracnose in Phaseolus vulgaris. Phytopathology 78:650 655.

Nei, M. 1972. Genetic distance between populations. Amer. Naturalist 106:283-292.

Pastor-Corrales, M.A. 1991. Estandarización de variedades diferenciales y de designación de razas de Colletotrichum lindemuthianum. Phytopathology 81:694 (abstract).

Pastor-Corrales, M.A. 1996. Traditional and molecular confirmation of the coevolution of beans and pathogens in Latin America. Annu. Rpt. Bean Improv. Coop. 39:46-47.

Pastor-Corrales, M.A., O.A. Erazo, E.I. Estrada, and S.P. Singh. 1994. Inheritance of anthracnose resistance in common bean accession $G$ 2333. Plant Dis. 78:959-962.

Pastor-Corrales, M.A., M.M. Otoya, and A. Molina. 1995. Resistance to Colletotrichum lindemuthianum isolates from Middle America and Andean South America in different common bean races. Plant Dis. 79:63-67.

Pastor-Corrales, M.A. and J.C. Tu. 1989. Anthracnose, p. 77-104. In: H.F. Schwartz and M.A. Pastor-Corrales (eds.). Bean production problems in the tropics. CIAT, Cali, Colombia.

Rava, C.A., J. Molina, M. Kauffmann, and I. Briones. 1993. Determinación de razas fisiológicas de Colletotrichum lindemuthianum en Nicaragua. Fitopatol. Bras. 18:388-391.

Restrepo, S. 1994. DNA polymorphism and virulence variation of Colletotrichum lindemuthianum in Colombia. MS thesis. Univ. Paris IV, Paris-Grignon, France.

Rodriguez, R. 1991. Identificación de razas patogenicas de Colletotrichum 
lindemuthianum (Sacc. y Magn.) Scrib. en el estado de Durango mediante un sistema propuesto internacionalmente y respuesta de genótipos de frijol tolerantes a sequia a razas del patógeno. MS thesis, Parasitologia Agricola, Universidad Autonoma Agraria "Antonio Narro", Buenavista, Mexico.

Rosas, J.C., O.I. Varela, and J.S. Beaver. 1997. Registration of 'Tio Canela-75' small red bean (Race Mesoamerica). Crop Sci. 37:1391.

Sandlin, C.M, J.R. Stcadman, C.M. Araya, and D.P. Coyne. 1996. Bean rust pathogen isolates show specific virulence to Andean-origin bean landraces. Annu. Rpt. Bean Improv. Coop 39:80-81.

Schwartz, H. F., M.A. Pastor-Corrales, and S. Singh. 1982. New sources of resistance to anthracnose and angular leaf spot of beans (Phaseolus vulgaris). Euphytica 31:741-754.

Sicard, D., Y. Michalakis, M. Dron, and C. Neema. 1997. Genetic diversity and pathogenic variation of Colletotrichum lindemuthianum in the three centers of diversity of its host, Phaseolus vulgaris. Phytopathology, 87:807-813.

Singh, S.P., P. Gepts, and D. Debouck. 1991. Races of common bean (Phaseolus vulgaris, Fabaceae). Econ. Bot. 45:379-396.

Sutton, B.C. 1992. The genus Glomerella and its anamorph Colletotrichum, p. 1-26. In: J.A. Bailey and M.J. Jeger (eds.). Colletotrichum-Biology, pathology and control. C.A.B. Intl., Wallingford, U.K.
Tu, J.C. 1988. Control of bean anthracnose caused by delta and lambda races of Colletotrichum lindemuthianum in Canada. Plant Dis. 72:5-7.

Tu, J.C. 1992. Colletotrichum lindemuthianum on bean. Population dynamics of the pathogen and breeding for resistance, p. 203-224. In: J.A. Bailey and M.J. Jeger (eds.). Colletotrichum-Biology, pathology and control. C.A.B. Intl., Wallingford, U.K.

Voysest, O., M.C. Valencia, and M.C. Amexquita. 1994. Genetic diversity among Latin American Andean and Mesoamerican common bean cultivars. Crop. Sci. 34:1100-1110.

Waterhouse, W.L. 1955. Studies of bean anthracnose in Australia. Proc. Linn. Soc. N.S.W. 80:71-83.

Young, R.A. and J.D. Kelly. 1996a. Characterization of the genetic resistance to Colletotrichum lindemuthianum in common bean differential cultivars. Plant Dis. 80:650-654.

Young, R.A. and J.D. Kelly. 1996b. Is the anthracnose resistance 'A' gene the same in cultivars belonging to both bean gene pools? Annu. Rpt. Bean Improv. Coop. 39:296-297.

Young, R.A. and J.D. Kelly. 1997. RAPD markers linked to three major anthracnose resistance genes in common bean. Crop Sci. 37:940-946.

Young, R.A., M. Melotto, R.O. Nodari, and J.D. Kelly. 1998. Marker assisted dissection of oligogenic anthracnose resistance in the common bean cultivar, G2333. Theor. Appl. Genet. 96:87-94. 